\title{
CREATION AND REVITALIZATION OF THE ESTONIAN NATIONAL REGISTER OF ANTHROPOMETRIC DATA
}

\author{
ENE-MARgit Tirt
}

Faculty of Mathematics and Computer Science, University of Tartu, Tartu, Estonia

\begin{abstract}
Anthropmetric data have always been of interest for scientists. They have also great practical value for different groups of people: tailors, designers and also health care specialists. Anthropological data are different in different geographical areas and also change in time. That is why it is important to save also results of older anthropometrical measurements. In Estonia the anthropometrical measurements have been made by different researchers since the 18th century. The Group of Physical Anthropology at the University of Tartu (initiated by prof Helje Kaarma) was especially active in gathering anthropometric data. The data were saved in the Anthropometic Register. Unfortunately, the register had no financial support and so its activities stopped. In summer 2016 the group of people interested in saving the historical anthropometric data started revitalising the Register of Anthropological Data. Hopefully, it will be possible to use the Estonian Social Science Data Archive for this purpose.
\end{abstract}

Keywords: anthropometric data; measurements; register; database

\section{WHY DO WE NEED DATA OF ANTHROPOMETRIC MEASUREMENTS?}

Anthropometric data have always been of interest for scientists and also for ordinary people. These data have great practical value for different groups of people: tailors, couturiers and footwear designers. These data are also important for people dealing with nutrition problems and with ergonomic solutions in different areas. Another very practical question: how to select the talented ones from among young children to motivate them to train with the aim to get good results in the future? 
Anthropometric characteristics are different in different geographical areas, different races and social groups. What is more surprising - they are not stable in time but have changed markedly; especially rapid changes have been observed during the last century in almost all developed countries. For scientists the problems connected with changes of anthropometric data in time and in space are of great interest. Nobody can say what the reason is why men today are taller than fifty years ago and why children reach puberty earlier than 20 years ago. The answer - changed living conditions - is not exhaustive.

That is why the anthropometric data of different age and social groups, measured at different time points in different places are of high scientific interest nowadays too.

\section{HISTORY OF ANTHROPOMETRIC MEASUREMENTS IN ESTONIA}

Anthropometric measurements in Estonia have a rather long history.

The starting point of anthropometric research in Estonia is connected with Karl Ernst von Baer who published Vorlesungen über Anthropologie für den Selbstunterricht in 1824 [1]. By the end of the $19^{\text {th }}$ century several doctoral theses on anthropology had been defended in the University of Tartu [2]. More active research in the area started in the $20^{\text {th }}$ century.

The Estonian Encyclopaedia (Eesti Entsüklopeedia) [3], published in the 1930s, also includes quite a long article on Estonians. This article gives a thorough anthropometric description of Estonians with 13 body and 10 head measurements for both men and women. These measurements were taken by J. Villems (1926) and J. Aul (1929). In the references, the measurements and analyses made by H. Reiman (1931), H. Madissoon (1926) and R. Weinberg (1903) are also mentioned. This was the time when eugenics was quite popular in many countries, and some scientists (especially anthropologists and medics) were included in the movement. Interest in race problems also determined the choice of the anthropometric characteristics measured. In this sense, it is interesting to know that in $1934 \mathrm{~J}$. Aul published an article "The Aryan race does not exist" in the Estonian newspaper Vaba Maa (Free Country) [4]. So, the Estonian population was anthropologically quite comprehensively measured and analysed before the Second World War. The papers concerning anthropometric data of Estonians were published in different issues. For instance, the data on enlistees "Weight, height and hands strength of young soldiers" were published in the Statistical Monthly of Estonia. The newspaper Päevaleht published an analysis of anthropometric data of students of the University of Tartu 
in 1934. By all data the conclusion was made: Estonians are among the tallest people in Europe and also in the world. This was an important fact for the representatives of a small country.

After the Second World War anthropological research in Estonia, occupied by Soviet Union, continued, with J. Aul being the supervisor of the area. As a new branch, research in palaeoanthropology of Estonia was initiated by Karin Mark who was also interested in ethnic anthropology with the aim of checking the hypothesis about the Mongolic heritage in Estonian and Finnish populations. The most impressive work K. Mark did was the comparative description of multiple ethnicities living in the Soviet Union where the main attention was paid to Finno-Ugric ethnic groups. The measurements made by K. Mark herself are on a very high methodological level and eminently accurate. The results of the measurements made during expeditions in 1955-1980 are summarised by K. Mark's disciple Leiu Heapost in the book Physical Anthropology of FinnoUgric Peoples (Tallinn, 2014, 542 pages) [5].

At the same time, anthropological measurements were also made at the University of Tartu. It was very important to measure children with the aim to create new standards for height and weight of children of all ages. Due to rapid change, the old standards created in the 1930s did not fit any more, Estonian children were also somewhat bigger than Russian ones, and so the standards created for the Soviet Union did not fit either. The group of anthropologists also made measurements of pregnant women (with the aim to forecast the weight of the neonate and to discover the possible disorders in development), athletes, schoolchildren of different ages, etc.

\section{CREATION OF THE ANTHROPOMETRIC REGISTER (AR)}

Soon after Estonia had gained independence, the Centre for Physical Anthropology was created in the University of Tartu with Helje Kaarma as the head of the centre. This happened in 1993. The centre continued the earlier activities of the working group making anthropometric measurements with the aim of creating the norms for different age-groups of Estonians and creating the classification rules of body structure for different groups of population.

Soon the idea arose that the results of measurements should be saved for further usage. So, in 1994 the National Register of Anthropometric Data in Estonia (NRADE) was initiated by the Centre for Physical Anthropology in the University of Tartu and established by the Ministry of Social Affairs. 
The aims of the Register were fixed as follows:

- to save (archive) the existing anthropometric data (with necessary metadata), including historical data);

- to create possibilities for the use (secondary analysis, comparison, publication) of anthropometric data gathered earlier in Estonia/by Estonian researchers.

The potential users of the Register were scientists, medics, sports trainers, people working in practical areas as design, ergonomics and nutrition, also students and pupils doing projects and research.

\section{REGISTER OR DATA-SET?}

In fact, the Register was not a register in the statistical sense of the word. It was a collection of different independent data-sets containing, in general, nonidentified information.

In the starting period of the Register, there was an idea to identify the data using ID-codes, which would have made it possible to monitor the development of children and youngsters or to follow the changes in the condition of a patient, etc. It turned out, however, that following security rules, in most cases anthropometric measurements should be anonymous, not identified. Still, it was technically possible to use identified data-sets as well. Repeated measuring was not eliminated either, although it happened rather rarely.

\section{WHAT ARE ANTHROPOMETRIC MEASUREMENTS?}

The best-known anthropometric data are height and weight, and BMI, which is derived from them. There are, however, many other measurements used in different anthropometrical surveys. In 1998 the standard data-set for the Register included 40 anthropometric variables. Additionally, the data on fat layers and dermatoglyphics might be added. In special surveys, other variables characterising some diagnoses, pregnancy, physical capability, ethnicity, etc. might be added. As background variables, the sex and age in measuring are necessary, also the place (area in Estonia) and ethnic nationality are desirable.

In general, the anthropometric variables are defined uniquely, but in different data-sets some differences in measurement methodology may arise. For instance, in Mark's data of Finno-Ugric peoples quite special variables characterising the Mongolic heritage were measured. 
In general, the set of variables measured is different in different surveys depending on the scientific goals of the research.

After the AR had been created, a new publication - Yearbook of the Estonian Anthropometric Register (YEAR) - was also created. This was a collection of papers in Estonian, mainly reflecting the analyses connected with data from the AR. This was another periodic publication on anthropology which the University of Tartu published at that time, as a yearly scientific compendium Papers on Anthropology (in English) existed already. Five issues of the yearbook were published, 1130 pages in total, during five years 1998-2002. These were the most active and successful years in the work of the Register.

\section{STRUCTURE AND ORGANISATION OF AR}

The IT solution of the register was designed by Toomas Viirsalu from the IT enterprise APT. The solution was made using the SAS-environment and at the beginning the servers of the University of Tartu were used. The owner of the Register was the Centre for Physical Anthropology and its holders were also connected with this centre, but most of them had a background in mathematical statistics.

During its first working years the Register developed quite rapidly. Kandela Oun, the Register holder in 2000, published a paper about the Register in the Yearbook [6]. There she said that the only about five-year-old Register already contained 40 different surveys with more than 77000 records in total, where in some cases the number of variables measured was quite big. The data were gained from different sources: there were data measured by anthropologists but also data received from schools (measured by school nurses) or from GPs. In many surveys babies were measured.

The Register worked practically without any financial support, so time by time there were no holders. At last the only person connected with the AR was the retired statistician Säde Koskel who passed away unexpectedly in 2013. A memory stick with some (unreadable) data was the only information about the Register that was received from her family.

\section{REVITALISING OF REGISTER OF ANTHROPOLOGICAL DATA}

In summer 2016 the idea arose to discover and restore the data that were saved in the Register and find a possibility to archive all old anthropometric data on Estonians that could be found. A stimulus for this initiative was the project of 
a computer-based statistics program for Estonian schools, developed together with Wolfram Company and the need for data available for pupils [7].

A meeting of representatives of the Centre of Physical Anthropology and other institutions having anthropometric data discussed the possibilities of archiving the data. All participants agreed that the anthropometric data measured in different time periods in Estonia are so valuable that they should be saved. The main reasons were not new, here it is appropriate to refer to the document written about 20 years ago, when the Register was established (for the first time) [8]:

1. Data collected by researchers to achieve some scientific aim can serve in other researches in the future. Sometimes the same group might also be interested in the data to discover possible changes and developments.

2. Combining different data-sets measured at different times and places offers good opportunities for making comparisons and finding differences characterising the Estonian population.

3. Application of historical data and combining different resources is a very contemporary approach when the methodology of usage big data is a popular and growing trend.

It should also be mentioned that several surveys are rather poorly analysed, as in some cases only the averages and standard deviations of data-groups have been published.

The decision was reached that the most suitable solution for archiving the existing data is using the Estonian Social Science Data Archive (Eesti Sotsiaalteaduslik Andmearhiiv, ESTA) [9], which is administered by Rein Murakas and belongs to the Institute of Social Sciences, University of Tartu.

The negotiations with ESTA have started and the first digital anthropometric materials have been given over to ESTA. Hopefully they will soon be accessible for all people interested in them.

\section{REFERENCES}

1. Karl Ernst von Baer, https://et.wikipedia.org/wiki/Karl_Ernst_von_Baer

2. Tammiksaar E. (1999). Jooni K. E. von Baeri tegevusest antropoloogina - Yearbook of the Estonian Anthropometric Register, 1999, 191-203

3. Eestlased (1932). Eesti Entsüklopeedia, vihik 3.

4. Juhan Aul. https://et.wikipedia.org/wiki/Juhan_Aul

5. Mark K., Heapost L. (2014). Soome-Ugri rahvaste füüsiline antropoloogia. Tallinn: Teaduste Akadeemia Kirjastus. 
6. Õun K. (2000). Ülevaade Eesti antropmeetriaregistrist. Yearbook of the Estonian Anthropometric Register, 2000, 170-178.

7. Kund O. (2014). Eesti 31 koolis on töös arvutipõhise matemaatika katseprojekt. http://www.postimees.ee/2734340/eesti-31-koolis-on-toos-arvutipohisematemaatika-katseprojekt/

8. Tiit E.-M. (1998). Antropomeetriaregistrist. Yearbook of the Estonian Anthropometric Register, 1998, 9-16.

9. Eesti Sotsiaalteaduslik Andmearhiiv ESTA. http://psych.ut.ee/esta/

\section{Address for correspondence:}

Ene-Margit Tiit

Institute of Mathematical Statistics

Faculty of Mathematics and Computer Science

University of Tartu, Tartu, Estonia

J. Liivi 2-513, 50409 Tartu, Estonia

E-mail:ene.tiit@ut.ee 